HStud 28 (2014)2, 255-273

DOI: $10.1556 /$ HStud.28.2014.2.4

\title{
FORGOTTEN ERA, FORGOTTEN PEOPLE: THE NORTH KOREAN DIASPORA
}

\author{
BOGOOK KIM \\ Hankuk University of Foreign Studies \\ Republic of Korea \\ E-mail: kimbogook@hufs.ac.kr
}

\begin{abstract}
Since the middle of the 1990 s, more than 25,000 North Koreans have settled in South Korea, and researchers estimate that a further 20,000 North Korean refugees have migrated mainly to China, Southeast Asia, America, and Europe. Many of these refugees cite economic factors as the main motive for their escape, which more or less coincided with the North Korean famine, but before the 1990s there were two other periods that saw relatively large-scale emigration from North Korea, which occurred for other reasons. This paper identifies and compares the three periods, using archival sources from Korea, Hungary, and the former Soviet Union. It also uses the representative case of a North Korean medical student in Hungary to provide a unique perspective on a number of important historical events, including the August Incident in North Korea and the Hungarian Revolution of 1956.
\end{abstract}

Keywords: Korean Diaspora, Hungarian Revolution, Korean War, Soviet Union, confidential documents of foreign affairs, National Archives of Hungary and Korea

\section{Introduction}

The history of the Korean Diaspora could be said to have begun with the fall of Gojoseon around the 108 B.C. or when many displaced people moved to Japan after Baekje fell in 660. Because of many national disturbances, such as the Japanese invasion of 1592 and political disruption at the end of the $19^{\text {th }}$ century, many Koreans established themselves overseas, either voluntarily or by compulsion, after turning their backs on their own country. Today they constitute a Korean Diaspora around the world, in places like America, China, Japan, and Russia. One argument about the Korean Diaspora that has never been resolved relates to the North Korean Diaspora. There is a range of opinion on the subject, ${ }^{1}$ starting from whether North Korean Diaspora can even be regarded as a diaspora ${ }^{2}$ in the traditional sense. Terms like "North Korean defectors", "North Korean immigrants", "North Korean refugees", and "North Korean migrants" are used widely to describe North Koreans who have left North Korea. This study defines the North 
Korean Diaspora as those North Koreans who escaped from North Korea after the government was established or who settled down overseas after rejecting orders to return. The study recognizes the aforementioned diversity of opinion regarding the application of the term diaspora but uses it to avoid confusing future researchers by creating another term. The application of the term is diachronic and restricts its use to "Wollamin", mainly the escapees who defected to South Korea before and after the establishment of the North Korean government in 1948 and during the Korean War; "defected veterans", who escaped to South Korea after the war ended; "refugees" who escaped to foreign countries from North Korea; and "North Korean defectors" since the early 1990s. After the North Korean government was established, many immigrants established North Korean diasporic communities in South Korea or elsewhere, such as China, the Soviet Union (Russia), and Southeast Asia. When the present North Korean Diaspora is compared to that of the past, economic factors are more significant in explaining their formation than used to be the case. ${ }^{3}$

The data and studies on those who escaped North Korea after the establishment of the North Korean government and during the Korean War are growing continuously, especially on the diaspora that has arisen since the early 1990s; studies on the earlier diaspora, from the mid-1950s to the early 1960s, are fewer. Strictly speaking the diaspora comprised of mainly war orphans and students studying abroad, who were accepted by countries like the former Soviet Union, China, and many of the East European countries. After the North Korean government ordered them to return, some of them defied the order and remained in these countries or fled to other places as North Korean diasporas. The number of refugees who fled to Europe was not large, and most of those involved turned their backs on North Korea for ideological reasons. The main reason for the inadequacy of research on them could be insufficient data.

Much of the data that was previously difficult to access is now available to the public, following the removal of the so-called Iron Curtain across the former Soviet Union and Eastern Europe. Many of the better studies were made possible by the availability of the new data. This diaspora is particularly worth studying because it explains the reasons behind the disruption of the diasporic process, which only resumed in the mid-1990s.

This study divides the diaspora into three main periods. In order to analyze the communities that were established in Europe from the mid-1950s to the early 1960 s - the second period - the study examines the life of a North Korean student studying abroad. The study makes use of Hungarian diplomatic documents from the National Archives of Hungary (NAH) and Korean diplomatic documents from the Diplomatic Archives of the Ministry of Foreign Affairs and Trade, Republic of Korea (DAROK). This case study exemplifies a pattern of refusals to return by students studying abroad in Eastern Europe including those in the Soviet Union 
that was so common that a case can be made for treating those who fled during this period as a separate diaspora. The study also examines how cases such as this one, occurring within the context of a changing Eastern Europe, affected the North Korean government. It also explores how North Korean students overseas viewed the world at the time and identifies common features among North Korean diasporas that have until now been regarded as separate and distinct.

\section{The Three Periods of the North Korean Diaspora}

As has been mentioned above, this study recognizes that the meaning of the term "North Korean Diaspora" is open to contestation, so the term is used with a restricted meaning, limiting its application to those who possessed North Korean citizenship once the North Korean government was established and who sought new homes outside North Korea. The diaspora is categorized into three periods. The first period covers the years from the establishment of the North Korean government in 1948 to the end of the Korean War in 1953. This period could be subdivided into before/after 1948 and the Korean War (1950-53), ${ }^{4}$ but since the periods are connected and most of the migrants moved to South Korea, it is treated as one period. ${ }^{5}$ The number involved could be anything from 500,000 to 4.5 million people, depending on classification, but South Korean scholars estimate the number to be between 550,000 and 650,000. ${ }^{6}$ Because those involved moved to South Korea, which had the same language and culture, it is reasonable to dispute the use of the term diaspora in its usual sense. ${ }^{7}$ However, whether or not South and North Korea recognize each other as independent countries, the ambivalent attitude that the Wollamin displayed meet the criteria for diaspora as defined by Mudimbe and Engel, ${ }^{8}$ who employ an expanded concept of the term. It certainly would not be a stretch to include the Wollamin in the North Korean Diaspora on the basis of Tölölyan's definition of the term, ${ }^{9}$ which expands to include immigrants, expatriates, guest workers, exile communities, overseas communities, and ethnic communities.

After the Korean War ended, many North Koreans left their homes and moved abroad, but while the timing of their departure is connected to the end of the war, this study assigns them to a different period because most of them were sent abroad under government direction. The migrants from this period belong, for the most part, to one of two groups: war orphans sent abroad to be educated ${ }^{10}$ and young North Koreans sent overseas to other socialist countries to acquire skills to help restore postwar Korea. The number involved could be more than 30,000 people, but data sources are insufficient in number and disagree. ${ }^{11}$ Moreover, what data we have comes from personal sources; legitimate, scholarly studies that put them into context in relation to North Korea are lacking. Of course, research 
should include the accounts of those involved, as well as data from North Korea and the countries targeted for education and study, but this has not been possible because the data has not been accessed - except for a few countries like the Soviet Union, China, and Japan - and because the oral statements are not diverse or sufficient enough. Nevertheless, research is still being carried out, and it has become easier because of accessibility to data concerning those who stayed in the Soviet Union, China, and Japan, which provide relatively more people for research. Such studies as there are, however, deal with their subjects as returnees rather than as members of the North Korean Diaspora. Of course, it would be unreasonable to include all North Korean emigrants as members of the diaspora, ${ }^{12}$ because many of them left North Korea temporarily and their return was prearranged, even if precise dates were not set. Those who rejected the order to return to North Korea or who chose not to return and settled in a foreign country could be seen as members of the diaspora, however, and this study deals with them. From what we know, most North Korean Diaspora groups from this period formed in the Soviet Bloc countries, but also Japan and China. It is presumed that the number decreased rapidly after North Korea's forced repatriation measures, which continued from the mid-1950s to the early 1960s. Some North Koreans disobeyed the government and still live abroad, as citizens of their host countries, as stateless individuals, or as South Korean citizens. From the mid-1960s to the mid-1990s, there was nothing resembling the previous outflow of manpower from North Korea. Many students were sent abroad to study in Europe and the United States, particularly in the $1980 \mathrm{~s},{ }^{13}$ but we can assume that their management was very strict, and it would be appropriate to regard them as participants in one country's special but ordinary activities, be it short-term study abroad or overseas deployment of manpower.

The third period of the diaspora covers the period from the mid-1990s to the present. Research on the period is accumulating steadily. The number of North Koreans who settled in South Korea increased significantly in 1992, and by 2013, the number had reached $26,124 .{ }^{14}$ It is estimated that there are between 12,000 and 20,000 escapees in China ${ }^{15}$ and that several thousand more have settled in the United States, Canada, and Europe. ${ }^{16}$ Most of them were pursuing a better economic life; this period of the diaspora began during North Korea's food shortages in the mid-1990s and accelerated after the United States enacted the North Korean Human Rights Act of $2004^{17}$ and the West officially recognized the status of North Korean escapees. The number of those escaping has dropped recently because of new measures introduced by the North Korean government to prevent escape, but many experts believe it will not be able to contain its citizens' desire to escape for very long if internal sanctions are eased in any way. 


\section{The Diaspora in the Second Half of the 1950s}

From the perspective of the North Korean Diaspora, circumstances in North Korea after the outbreak of the Korean War were little different to those in South Korea. After the war, however, the need to acquire the advanced skills that were unavailable, except abroad, made outward migration unavoidable. Other socialist countries agreed to accept up to 30,000 war orphans, sent by the North Korean government to study in China, the Soviet Union, Eastern European countries, and Mongolia. Most of them were sent to China, although it is said that not all of them were war orphans; some were the children of high-level North Korean officials. ${ }^{18}$ Most of these were summoned back to North Korea around 1959, mainly because the approximately 250,000 members of the Chinese People's Volunteer Army, which had participated in the reconstruction of North Korea after the war, had completed their withdrawal in October $1958 .{ }^{19}$ Since the returnees had acquired skills and knowledge from countries more advanced than North Korea, they contributed greatly to the reconstruction of North Korea. Recent studies have focused on their role in the development of North Korean society (or North Korea). ${ }^{20}$ Data on students in Eastern Europe has not been included, however, because of limited access, and those studies that have been carried out focus on the students' activities once they had returned rather than from the perspective of the diaspora. Information about students' lives in the Soviet Bloc is important because although they shared the same philosophy and ideology as North Korea, political conditions were very different, and those who had experience of both societies can provide a unique perspective. In addition, their perspective constitutes something more than just personal experience. Although they were not members of an organized movement, the students shared a common attitude of hostility toward the North Korean system and a preference for exile in the West. ${ }^{21}$ This was not something North Korean leaders would have welcomed and could be one of the reasons why the regime maintained relatively strict policies on study abroad and kept a close eye on those it sent to the Soviet Union and Eastern Europe, although the main reason for this attitude had more to do with North Korea's internal political background and the international environment. To understand this, we must examine the political situations in North Korea and Eastern Europe in the mid-1950s, as well as North Korea's conflicts with China and the Soviet Union over the August Incident of 1956, among other things. This incident led to acceleration in the withdrawal of the Chinese People's Army, ${ }^{22}$ which meant a serious lack of labor for postwar reconstruction, so the government came up with the policy of recalling many of those abroad. The incident, which is the only collective civilian attempt to ever challenge the supreme power in North Korea, greatly influenced the political landscape of North Korea and provided the impetus for placing the Juche idea, North Korea's ruling ideology, ahead of political ideology. Moreover, the middle 
of 1956 was a period full of tension in Eastern Europe, where the Polish and Hungarian Revolutions were taking place in the wake of the $20^{\text {th }}$ convention of the Communist Party of the Soviet Union, when criticism of Stalin began, albeit behind closed doors. ${ }^{23}$ Under these circumstances, an examination of the ideas and opinions of those North Koreans who chose to stay in Eastern Europe rather than return home offers much of value.

\section{Dossier on Csö In-huan (Inhwan Choi) ${ }^{24}$}

Inhwan Choi was born on March 10, 1934, in Euiju, Pyonganbuk-do. After finishing high school ${ }^{25}$ in Euiju in September 1953, he studied at a medical school in Budapest, Hungary, on a scholarship. When the Hungarian Revolution occurred in October 1956, he fought alongside the Hungarian people against the Soviet Union's armed crackdown. ${ }^{26}$ After the Revolution was suppressed by force, he fled ${ }^{27}$ to Yugoslavia, where he was able to stay for nine months with the help of the Ministry of Interior. He obtained the status of political refugee there ${ }^{28}$ before moving to Switzerland. ${ }^{29}$ He arrived in Zürich ${ }^{30}$ on September 7, 1957, and while there, he asked for help from Won Yil Sohn, ${ }^{31}$ who was the minister in the South Korean Consulate, located in Bonn, the capital of West Germany. On Sohn's recommendation, Choi was able to continue his studies at a Zürich medical school and receive financial support from the American-Korean Foundation, ${ }^{32}$ following a request from Sohn to Ambassador Yu Chan Yang of South Korean Embassy in Washington, D.C. Choi received a South Korean passport issued by the Korean Consulate in Bonn around March 1958 and obtained Korean citizenship. ${ }^{33}$ Toward the end of July 1959, he visited the Chinese Embassy in Bern, Switzerland, and tried to express his political views, arguing the need for a union or confederation between North Korea and China based on Marxism-Leninism. However, because of problems with the language, he could not converse smoothly, so he expressed his opinions in a letter, which he wrote at the suggestion of the staff at the Chinese Embassy. ${ }^{34}$ When he did not receive any response from the Chinese Embassy, he visited the Hungarian Consulate ${ }^{35}$ in Bern at the end of October. On October 27, he sent a long letter to the Consulate that included his feelings, political views, and his interpretation of the international political situation, based on his experience of the 1956 Hungarian Revolution. In that letter, he requested help to study Chinese in China for one year so that he could work in the Hungarian Embassy in Beijing, which seems a bit absurd now. ${ }^{36}$ Receiving no reply, he sent another letter ${ }^{37}$ in early December to hurry things up. ${ }^{38}$ Up to this point, he had wanted to go to China in order to realize his political ideals and did not show any intention of going to South Korea, from which he received financial and administrative support, or to North Korea, his homeland. ${ }^{39}$ Suddenly, however, he 
changed his attitude, and on January 21, 1960, he applied for a Hungarian entry visa, with a document written in his own hand, ${ }^{40}$ to the Hungarian Consulate in Bern. ${ }^{41}$ On January 27 , the Hungarian consul directly signed and forwarded Choi's official application ${ }^{42}$ to the Passport Division of the MFAH. The day before, the protocol department of the MFAH saw Taehwa Kim, an attaché of the North Korean Embassy in Budapest, notified him that Inhwan Choi had sent an application for a Hungarian entry visa, and told him that they would process this according to the requirements of the North Korean Embassy. ${ }^{43}$ One month later, Kim requested that the MFAH allow Inhwan Choi to enter Hungary and for the Ministry of the Interior of Hungary (MIH) to follow him "illegally" (illegálisan) from the time he arrived to the time he left Hungary. ${ }^{44}$ The MFAH sent a confidential document to László Földes, the vice-minister of the MIH, informing him that Choi had specified the length of his visit to be 2-3 months on the application for an entry visa, and requested the MIH's cooperation so that it could follow him during his visit. ${ }^{45}$ The MIH replied on April 14, agreeing with the request and asked for Choi's visit to be reduced to three weeks or one month if the North Korean Embassy would allow it. ${ }^{46}$ Upon receiving this request through the MFAH, ${ }^{47}$ the North Korean Embassy in Budapest replied that once Choi arrived in Budapest, they would collect his South Korean passport, issue another one (más útlevelet), and issue an exit visa immediately because he would be repatriated to Pyongyang. ${ }^{48}$

\section{Comparison of Diasporas}

As mentioned earlier, studies on those who left North Korea for Europe between the mid-1950s and early 1960s have been inadequate because of the lack of data. As a witness to the events of that time, Inhwan Choi provides a valuable and interesting case. Rather than interpret his exile and return as the consequences of his own individual and unique circumstances, we can regard them as events that occurred in the middle of North Korea's internal crackdown that accompanied the frozen political atmosphere that arose after the August Incident, the uprisings of the Polish and Hungarian peoples against Stalinist rule, and the denigration of Stalin that began at the 20th convention of the Communist Party of the Soviet Union. It was during this period that not just Choi but many other North Korean students defected or disobeyed the order to return to North Korea, suggesting that the above perspective is warranted. The $20^{\text {th }}$ Convention of Communist Party of the Soviet Union was held on February of 1956. It affected not only the events leading to the August Incident, but also to the Hungarian Revolution of 1956. The August Incident caused many of North Korean diasporas. Even though events were not limited to one area or country, they can be looked at as a group phenomenon, al- 
beit one without a systematic intelligence network, and it is possible to interpret the Inhwan Choi case on that basis. Thus, if we look at those who left North Korea right after the establishment of the North Korean government and because of the Korean War as the first set of defectors, then those like Choi can be regarded as the second set. A period of stability then followed as the regime was established and the government's strict policies prevented any further diaspora from occurring. The collapse of those policies in the early 1990s led to the emergence of a third set of defectors, which persists to this day.

\section{Control of Students Overseas}

A further reason to pay attention to the North Korean Diaspora of the mid-1950s to the early 1960 s is that the North Korean government turned to strong management and control of overseas students in light of such dissident activity, reducing the numbers sent abroad significantly. ${ }^{49}$ Such activity could be seen by the North Korean government as a major impediment to solidifying the system and as damaging to the country's reputation abroad. The government actively monitored and controlled the students because it regarded them as potential forces of opposition. ${ }^{50}$ In the case of Inhwan Choi, Dongcheol Choi, the North Korean ambassador in Budapest, personally asked the Yugoslavian Embassy in Budapest about his escape to Yugoslavia and followed his activities in Yugoslavia. ${ }^{51}$ The fact that the North Korean government was aware of Inhwan Choi's statement ${ }^{52}$ criticizing North Korea on a Munich radio station also suggests that they kept an eye on his activities systematically.

The actions that the North Korean government later took regarding deserters in regions other than Hungary increased in severity. For example, in the case of the four North Korean students who refused to return from Bulgaria, the North Korean ambassador was deported for tracking them down, kidnapping them, and locking them up. ${ }^{53}$ When Kim Il Sung visited Bulgaria in 1976 and 1986, he raised the issue of these four refugees with the Bulgarian government. ${ }^{54}$ Even in the Soviet Union, there were diplomatic problems when North Korean special agents pursued students who had disappeared, with the result that the North Korean ambassador in Moscow was eventually deported. ${ }^{55}$ It is possible that the North Korean government's diplomatically irrational decisions arose because it was attempting to "make examples" of the students for internal consumption, but it would also be difficult to deny that their actions show the political significance they attached to the students' actions. ${ }^{56}$ 


\section{The Propaganda War in Europe}

In the mid-1950s and early 1960s, the students' actions meant that the propaganda war between the two Koreas expanded across Europe. Most of the students wanted to continue studying where they were, not even thinking of South Korea as a place to live, but some of them came to the South Korean embassy and asked for South Korea's support. ${ }^{57}$ Among the diplomatic documents regarding these refugee students that were sent to Seoul from the South Korean Consulate in Bonn, there is something interesting. Chang Yoon-Kul, who was the first secretary at the South Korean Consulate in Bonn and worked as the acting minister, reported information regarding the purges that followed the August Incident, as follows:

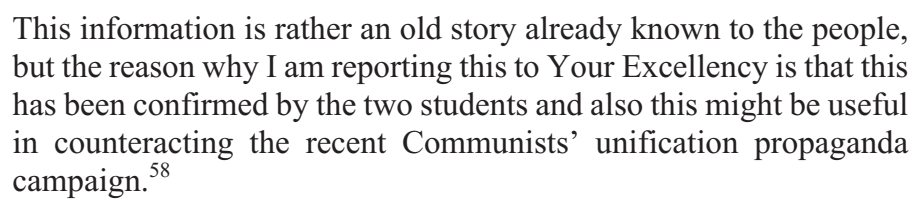
but the reason why I am reporting this to Your Excellency is that this has been confirmed by the two students and also this might be useful in counteracting the recent Communists' unification propaganda campaign. $^{58}$

It is not difficult to imagine, as the diplomatic documents suggest, that they tried to get information from those students who chose exile, ${ }^{59}$ and it shows that there were already discussions in progress regarding their political use or as a source of valuable information, focusing on the exile group in Europe. Unfortunately, North Korean data regarding this cannot be accessed, but the likelihood of North Korea responding in kind to South Korea's actions or even pre-empting them can be assumed. In the East Berlin (Spy) Incident, ${ }^{60}$ for example, the Korean Central Intelligence Agency (KCIA) announced that Korean students studying abroad in West Germany had contacted North Korea and had been in touch with the North Korean Embassy in East Germany since September 1958. ${ }^{61,62}$

\section{Conclusion}

Until now, studies of the lives and activities of North Koreans studying in Europe between the mid-1950s and the early 1960s have been inadequate because of insufficient data.

This paper tries to classify the occurrence of North Korean diaspora into three eras. The first era spans the time of establishment of the North Korean regime until the Korean War and the second era from the Korean War until the early 1960's when the war orphans and students studying abroad were ordered home to North Korea. The third era originated in the mid-1990s when the economic crisis happened in North Korea. While the first and third periods have been well documented, until now, studies on the lives and activities of North Koreans studying in 
Europe between the mid-1950s and the early 1960s have been inadequate because of insufficient data.

This has mainly been attributed to the lack of access to documented evidence. Moreover, this period has been difficult to research because at the time North Korean refugees mainly fled to formerly Communist countries, such as the East European countries, and the former Soviet Union. The period between the Korean War and the early 1960s, when North Korea laid the foundation for stability of political power after the August incident of 1956, belongs to the second term. In this paper, I have cited several sources from the Korean, Hungarian and Soviet Union archives. Especially, this paper is a dossier on a North Korean refugee (Inhwan Choi who studied in Hungary as a medical student on scholarship) complied from confidential diplomatic documents of the Ministry of Foreign Affairs of Hungary. Tracing the microcosm of this refugee's early years has provided glimpses into significant historical events, like the August Incident and the Hungarian Revolution of 1956. Moreover, the macrocosm surrounding this refugee has enabled to identify a point of contact between these two political events. A few documented memoirs and reminiscences of those historical events remain with the very man who experienced these events. Particularly, the refugee himself wrote a 10-page long memoir, and some official documents recorded by a third person exist, which are a rarity. These reveal how a particular refugee understood the state of the world around him, both as an individual and as someone thrown into the maelstrom of history. These documents are, therefore, valuable, transcending the perspective of one individual and setting them apart from the memoirs, autobiographies, and interviews that appear following his exile.

Besides the North Korean diaspora under consideration in this paper, the Hungarian sources additionally tell us some new facts, namely that North Korea anticipated the military dictatorship in South Korea right after the April Revolution and the so far unknown information of North Korean ex-ambassador in Moscow who was banished by ex-USSR for kidnapping.

It is regrettable that there was no possibility of reviewing the data of other countries in more detail and that it was not possible to make any significant contact with North Korean escapees in China and Japan, where the majority of those with North Korean citizenship lived, outside of Europe. I close this study in the hope that more research will be done in this field and that interest in it will be sustained.

\section{Abbreviations Used in This Paper}

DPRK Democratic People's Republic of Korea (North Korea)

NAH The National Archives of Hungary 


$\begin{array}{ll}\text { DAROK } & \text { Diplomatic Archives of the Republic of Korea } \\ \text { KCIA } & \text { Korean Central Intelligence Agency } \\ \text { HAHSS } & \text { Historical Archives of the Hungarian State Security } \\ \text { UNHCR } & \text { The United Nations Refugee Agency } \\ \text { AFPSU } & \text { Archive of Foreign Policy of the Soviet Union } \\ \text { MIH } & \text { Ministry of Interior of Hungary } \\ \text { MFAH } & \text { Ministry of Foreign Affairs of Hungary }\end{array}$

\section{Bibliography}

Brass, Paul R. 1996. "Ethnic Groups and Ethnic Identity Formation.” In Ethnicity, edited by John Hutchinson and D. Anthony Smith, 85-90. Oxford, New York: Oxford University Press.

Byelov, Valerie Alexeevich. 2003. Подготовка каgров gля зарубезньх стран в советских вузах. Калининград; Изд-во Калининградского гос. Университета (Quoted in Sin, Hyo-sook, 2005).

Chanlett-Avery, Emma, and Ian E. Rinheart. 2013. North Korea: U.S. Relations, Nuclear Diplomacy, and Internal Situation. Congressional Research Service, April 5.

Choi, Gwon-jin, and So-young Kim. 2012, "Life Stories of North Korean Students: Lives as Students Studying Abroad and as Refugees in Bulgaria." In: The Interrelationship between Bulgaria and Korea after the Second World War (Survey of archives and relevant publications). Sofia: Kamea, 91-117.

Colville, Rupert. 2006. Refugees 144 (3). UNHCR.

Department of State. 1974. "Northeast Asia." In Foreign Relations of the United States 1948: Volume VI. The Far East and Australasia, Washington: U.S. Government Printing Office, 646-1345.

Han, Sang-Jun. 2012. "The Reason for Withdrawal of the Chinese People's Volunteers and China-North Korea Relations.” Journal of Asia-Pacific Studies 19 (2): 5-39

Hartely, John. 2002. Communication, Culture and Media Studies: The Key Concepts. London, New York: Routledge.

Joung, Eun-lee. 2009. "Re-illumination of North Korean System through Life of Korean Residents in Japan Returning to North Korea: Focusing on Testimony of North Korean Defectors in Japan." Journal of Asiatic Studies 52 (3): 189-282

Joung, Eun-lee. 2011. "History of Market and Changes of Economic Structure in North Korea." Journal of Asiatic Studies 54 (1): 220-283

Kang, Jeong-Koo. 1992. "Study on the Motive and the Class Consciousness of Wollamin (North Korean Defectors) after Liberation." In: Korean Sociological Association, The Korean War and the Changes in Korean Society, 93-131. Seoul: Pulbit Publishing.

Kim, Bogook. 2012. Catalog of the Confidential Diplomatic Documents Concerning South Korea and North Korea from the Ministry of Foreign Affairs of Hungary (1945-1993). Seoul: Bread \& Roses Publishing Co.

Kim, Güm-csol. Egy modern Magyar-Koreai szótár koncepciója S.1, S.n. Master's thesis 1983.

Kim, Soo-am. 2012. "The Change of Actual Circumstances of North Korean Defectors in China and the Direction for Carrying out the Policy." EAI Asia Security Initiative Working Paper 29. Seoul: The East Asia Institute.

Koo, Haeu, and Hogeun Song. 2012. Genius Musician Chu Jeong Deserted by North Korea. Seoul: Zeitgeist.

Kwon, Tai Hwan. 1977. Demography of Korea: Population Change and Its Components, 1925-1966. Seoul: Seoul National University Press. 
Lankov, Andrei. 2005. Crisis in North Korea: The Failure of De-Stalinization, 1956. Honolulu: University of Hawaii Press.

Marienstras, R. 1989. "On the Notion of Diaspora." In: Minority Peoples in the Age of Nation-States, edited by G. Chaliand, 119-125. London: Pluto.

Molnár, Adrienne, Zsuzsanna Körösi, and Márkus Keller, eds. 2006. A forradalom emlékezete: Személyes történelem. Budapest: 56-os Intézet.

Mudimbe, V. Y., and Sabine Engel. 1999. “Introduction”, in "Diaspora and Immigration”, ed. Mudimbe with Engel, special issue, The South Atlantic Quarterly 98 (1/2): 4.

Park, Young-sil. 2006. "Chinese People's 'Volunteers' Aiding to and Retreat from North Korea during the Korean War and After.” Korean Studies Quarterly 29 (4): 265-291.

Razuvaev, Vladimir Nikolaevich. 2001. Razuvaev, Soviet Chief Military Advisor's Korean War Report. ROK Ministry of National Defense, Institute for Military History Compilation.

Safran, William. 1991. "Diasporas in Modern Societies: Myths of Homeland and Return." Diaspora: A Journal of Transnational Studies 1 (1): 83-99.

Sin, Hyo-sook. 2005. "Training and Reorganization of Higher Manpower in the Change of the North Korean Society (1945-1960).” North Korea Studies Review 8 (2): 39-83.

Szalontai, Balázs. 2005. Kim Il Sung in the Khrushchev Era. Stanford, California: Stanford University Press.

Tölölyan, K. 1991. “The Nation State and Its Others: In Lieu of a Preface.” Diaspora: A Journal of Transnational Studies 1 (1): 3-7.

Tölölyan, K. 1996. "Rethinking Diaspora(s): Stateless Power in the Transnational Moment." Diaspora: A Journal of Transnational Studies 5 (1): 3-36.

United States Government Accountability Office. 2010. "Humanitarian Assistance: Status of North Korean Refugee Resettlement and Asylum in the United States." Report to Congressional Requesters, June 2010.

Yoon, In-Jin. 2001. "North Korean Diaspora: North Korean Defectors Abroad and in South Korea." Development and Society 30 (1): 1-26.

\section{Materials from the Diplomatic Archives of Republic of Korea (DAROK)}

DAROK Class No. 729.5. Reg. No. 142-143, 145. Film No. G0001. Frame No. 0557-0866. 0933-1064

DAROK Class No. 743.73GE/KN 1957-1959. Reg. No. 329. Film No. K0001. Frame No. 0183

DAROK Class No. 743.73GE/KN 1957-1959. Reg. No. 329. Film No. K0001. Frame No. 0184

DAROK Class No. 743.73GE/KN 1957-1959. Reg. No. 329. Film No. K0001. Frame No. 0185

DAROK Class No. 743.73GE/KN 1957-1959. Reg. No. 329. Film No. K0001. Frame No. 0188

DAROK Class No. 743.73GE/KN 1957-1959. Reg. No. 329. Film No. K0001. Frame No. 0189-0190

DAROK Class No. 743.73GE/KN 1957-1959. Reg. No. 329. Film No. K0001. Frame No. 0192

DAROK Class No. 743.73GE/KN 1957-1959. Reg. No. 329. Film No. K0001. Frame No. 0193

DAROK Class No. 743.73GE/KN 1957-1959. Reg. No. 329. Film No. K0001. Frame No. 0194

DAROK Class No. 743.73GE/KN 1957-1959. Reg. No. 329. Film No. K0001. Frame No. 0195

DAROK Class No. 743.73GE/KN 1957-1959. Reg. No. 329. Film No. K0001. Frame No. 0199

DAROK Class No. 743.73GE/KN 1957-1959. Reg. No. 329. Film No. K0001. Frame No. 0200

DAROK Class No. 743.73GE/KN 1957-1959. Reg. No. 329. Film No. K0001. Frame No. 0201 
Materials from Historical Archives of Hungarian State Security (HAHSS)

HAHSS 3.2.4. K-84/1. 61

HAHSS 3.2.5. O-8-95/1. Svájci Magyar Emigráció 58

HAHSS 3.2.5. O-8-95/1-5.

\section{Materials from the National Archives of Hungary (NAH)}

NAH Roll No. 53694. Frame No. 200800002320

NAH Roll No. 53706. Frame No. 200800000063

NAH Roll No. 53706. Frame No. 200800000065

NAH Roll No. 53706. Frame No. 200800000066

NAH Roll No. 53706. Frame No. 200800000067

NAH Roll No. 53706. Frame No. 200800000068

NAH Roll No. 53706. Frame No. 200800000070

NAH Roll No. 53706. Frame No. 200800000073

NAH Roll No. 53706. Frame No. 20080000 0081-0082

NAH Roll No. 53706. Frame No. 200800000084

NAH Roll No. 53706. Frame No. 2008000000870088

NAH Roll No. 53706. Frame No. 200800000089

NAH Roll No. 53706. Frame No. 20080000 0092-0100

NAH Roll No. 53706. Frame No. 200800000110

NAH Box No. 43. Code No. 81-72. Document No. 0012

NAH XIX-J-1-k. Box No. 8. 1/25/3/1957

\section{Newspapers}

Dong-A Ilbo July 8, 1967, p. 1.

\section{Internet}

The White House Home Page: http://www.whitehouse.gov/the-press-office/2012/08/16/statementpress-secretary-hr-1402-hr-3670-hr-4240-s-3510 [Accessed: February 3, 2014].

Ministry of Unification of Republic of Korea Home Page: http://www.unikorea.go.kr/index.do ?menuCd=DOM_000000105006006000 [Accessed: February 3, 2014].

\section{Notes}

1 Given that South and North Koreans share an identical ethnicity, regardless of their differences in ideology and government, it is arguable that the North Korean Diaspora should be treated as a subdivision of the larger Korean Diaspora. It is worth noting that Hartely describes ethnicity as a concept related to the past and explains it in terms of community, neighbors, and 
cultural transformation. See John Hartely, Communication, Culture and Media Studies: The Key Concepts (London, New York: Routledge, 2002), 66. Brass defines ethnicity in terms of objective characteristics and subjective emotions. See Paul R. Brass, Ethnic Groups and Ethnic Identity Formation, in Ethnicity, edited by John Hutchinson and D. Anthony Smith (Oxford, New York: Oxford University Press, 1996), 85. At the very least, it is clear that the term "North Korean Diaspora" does not go uncontested.

2 Safran defines the term "diaspora" as applicable to any expatriate communities possessing several of the following features: 1. dispersal from the place of origin to two or more other places; 2. retention of a collective memory, fantasy, or myth about the homeland; 3 . a feeling that they are not - and possibly cannot be - part of the host society; 4 . a yearning for the homeland as the true, ideal home and for an eventual homecoming at the proper time; 5. a belief that they should, collectively, be committed to the motherland's security, prosperity, and restoration; 6 . an ongoing relationship with the mother country such that their ethnocommunal consciousness and sense of solidarity are strongly affected by that relationship. See William Safran, "Diasporas in Modern Societies: Myths of Homeland and Return", Diaspora: A Journal of Transnational Studies 1.1 (1991): 83-4.

3 For more details, see In-Jin Yoon, North Korean Diaspora: North Korean Defectors Abroad and in South Korea, Development and Society 30.1 (2001): 6.

4 Jeong-koo Kang mentions the Wollamins' anti-communist beliefs and the impact of the North Korean land reform of March 1946 in relation to their decision to defect. He is skeptical about regarding the period before the Korean War as one of genuine defection because the Wollamin who left were landowners and made up only $4 \%$ of the agricultural population. See Jeong-Koo Kang, Study on the Motive and the Class Consciousness of Wollamin (North Korean Defectors) after Liberation, in Korean Sociological Association, The Korean War and the Changes in Korean Society (Seoul: Pulbit Publishing, 1992), 98-9.

5 Some chose a country other than North or South Korea. For example, of 76 prisoners of war released after the truce, 50 settled in Brazil and 12 in Argentina, after passing through India with 12 Chinese prisoners. The other ten stayed in India or repatriated to North Korea. For more details, see DAROK, Class No. 729.5. Reg. No. 142-143, 145. Film No. G0001. Frame No. 0557-0866. 0933-1064.

6 Byeongok Cho notes that ordinary North Koreans with no contacts in the military or government struggle to live because the government devotes most of its budget to the military. Approximately 4.5 million North Koreans have moved to south of the $38^{\text {th }}$ Parallel. See Department of State, "Northeast Asia", in Foreign Relations of the United States 1948: Volume VI. The Far East and Australasia (Washington: U.S. Government Printing Office 1974), 1310. Jeong-koo Kang estimates that approximately 840,000 Wollamins moved during the truce period of 1945-53 (Kang, "Study on the Motive", 95-98). Tai Hwan Kwon estimates the number of Wollamin who defected at approximately 1.4 million for the same period; approximately 740,000 defected from 1945 to 1949, and 650,000 defected during the Korean War. A further 300,000 people defected to North Korea during the war. See Tai Hwan Kwon, Demography of Korea: Population Change and Its Components, 1925-1966 (Seoul: Seoul National University Press, 1977), 202-5.

7 The validity of including the Wollamins of this period in the diaspora can be debated. In addition, it might be appropriate to classify those North Koreans who defected and settled in South Korea as a "North Korean intra-diaspora." This study uses "North Korean diaspora" to avoid the use of too many terms.

8 "Members of diasporas define themselves in terms of at least a double identity, thus bracketing the unconditional fidelity associated with citizenship in a particular nation-state." Mudimbe, 
V. Y. and Sabine Engel, "Introduction," in "Diaspora and Immigration," ed. Mudimbe with Engel, special issue, The South Atlantic Quarterly 98.1/2 (1999): 4.

9 K. Tölölyan, "The Nation State and Its Others: In Lieu of a Preface”, Diaspora: A Journal of Transnational Studies 1.1 (1991): 4-5. Tölölyan regards the term "diaspora" as a promiscuously capacious category (Tölölyan "The Nation State", 8).

10 This actually happened during the Korean War. According to Razuvaev, more than 2,000 North Korean war orphans were sent overseas at the request of other socialist countries; for example, in 1951, 200 orphans went to Poland and 200 went to Hungary; in 1952, 200 went to Czechoslovakia, 1,500 went to Romania, 200 went to Bulgaria, and 200 went to the Mongolian People's Republic. China suggested that North Korea send 23,000 war orphans there to be educated. In early 1951, the International Federation of Red Cross and Red Crescent Societies (IFRC) executive committee planned to take 100 North Korean war orphans to the Soviet Union, but the plan foundered because of North Korea's refusal. The suggestion that the Soviet Union should take North Korean war orphans, even though North Korea had not requested it, appears in a report from February 1953. See Vladimir Nikolaevich Razuvaev, Soviet Chief Military Advisor's Korean War Report (ROK Ministry of National Defense, Institute for Military History Compilation, 2001), 13-16.

11 This number of 30,000 orphans is only an estimate based on the first Far East Division in the Archive of Foreign Policy of the Soviet Union (AFPSU) quoted in Sin, "Training and Reorganization of Higher Manpower in the Change of the North Korean Society (1945-1960)", North Korea Studies Review 8.2 (2005): 39-83. However, it seems that we cannot regard this as the only authentic source because with regard to the number of war orphans, these data are inconsistent with those reported by Razuvaev (2001), even though both originated from the former Soviet Union. With regard to data from Hungary, for example, Razuvaev said that 200 war orphans were sent between 1951 and 1952, but the AFPSU has no record of any being sent during that period (ibid). According to the testimony of Inhwan Choi, a North Korean student who settled temporarily in Switzerland after defecting from Hungary to Yugoslavia, approximately 700 people returned to North Korea, including those studying abroad, in January 1957 (NAH Roll No. 53706. Frame No. 20080000 0099). Hungarian administrative confidential documents are the most authentic sources in this regard because Hungary was one of the countries involved. They show that, on January 5, three groups arrived back in Pyongyang: 21 students; 375 students who were mainly war orphans, through Sopron in Hungary and Czechoslovakia; and approximately 400 students, mainly technical school students or university students (XIX-J-1-k. Box No. 8. 1/25/3/1957). According to AFPSU data, however, approximately 1,200 people returned to North Korea, all war orphans except for 110 students who were about to graduate in Hungary (AFPSU, quoted in Sin, "Training and Reorganization”, 68).

12 There is a theoretical justification for regarding North Korean war orphans who were sent overseas for an education within the category of diaspora. Marienstras points out that length of time abroad is an important aspect of diaspora. See R. Marienstras, "On the Notion of Diaspora", in Minority Peoples in the Age of Nation-States, edited by G. Chaliand (London: Pluto, 1989), 125. Tölölyan interprets the meaning of diaspora broadly and includes exile, loss, dislocation, helplessness, and pain in general as useful and proper signifiers in describing the features of dispersal. See K. Tölölyan, "Rethinking Diaspora(s): Stateless Power in the Transnational Moment", Diaspora: A Journal of Transnational Studies 5.1 (1996): 9.

13 In the 1970s, only 156 North Korean students entered higher education institutions in the Soviet Union, whereas for the years 1980-1985, 915 students enrolled (Byelov, quoted in Sin, "Training and Reorganization", 60). For Hungary, refer to Footnote 53.

14 South Korean Ministry of Unification, http://www.unikorea.go.kr/index.do?menuCd=DOM _000000105006006000 
15 Soo-am Kim, "The Change of Actual Circumstances of North Korean Defectors in China and the Direction for Carrying out the Policy", EAI Asia Security Initiative Working Paper 29 (Seoul: The East Asia Institute, 2012), 3.

16 Between October 2004 and March 2010, the United States granted refugee status to 94 North Koreans. See United States Government Accountability Office (GAO), "Humanitarian Assistance: Status of North Korean Refugee Resettlement and Asylum in the United States", Report to Congressional Requesters, June 2010: 12. Canada granted refugee status to 217 North Koreans between 2003 and 2009, the United Kingdom granted refugee status to 350 North Koreans between 2006 and 2009, and Germany granted refugee status to 191 North Koreans between 2000 and 2009 (GAO, "Humanitarian Assistance", 48-49).

17 President Obama signed the North Korea Human Rights Reauthorization Act of 2012 on August 16, 2012 (http://www.whitehouse.gov/the-press-office/2012/08/16/statement-press-secretary-hr-1402-hr-3670-hr-4240-s-3510). The original North Korea Human Rights was enacted in October 2004 when George W. Bush was in office and was extended for four more years in 2008. For more information, see Emma Chanlett-Avery and Ian E. Rinheart, North Korea: U.S. Relations, Nuclear Diplomacy, and Internal Situation. Congressional Research Service, April 5, 2013: 20-21.

18 Eun-lee Joung, "History of Market and Changes of Economic Structure in North Korea", Journal of Asiatic Studies 54.1 (2011): 228.

19 For more details on the withdrawal of the Chinese People's Volunteer Army, see Park, "Chinese People's 'Volunteers' Aiding to and Retreat from North Korea during the Korean War and After”, Korean Studies Quarterly 29.4 (2006): 265-291.

20 See Eun-lee Joung, "Re-illumination of North Korean System through Life of Korean Residents in Japan Returning to North Korea: Focusing on Testimony of North Korean Defectors in Japan", Journal of Asiatic Studies 52.3 (2009): 189-282.

21 Resistance and hostility to the regime was displayed on a number of occasions in the Soviet Union and Eastern Europe around this time, including defections by North Korean students in 1956 (see Footnote 51); a protest against Kim Il Sung that took place in Moscow in 1957, reported by the musician Jung Chu, who refused to return to North Korea from Moscow (see Footnote 55); and the refusal to return by four students who declared themselves exiles for ideological reasons in Bulgaria in the early 1960s (see Footnote 52).

22 See Sang-Jun Han, "The Reason for Withdrawal of the Chinese People's Volunteers and China-North Korea Relations”, Journal of Asia-Pacific Studies 19.2 (2012): 5-39.

23 The uprising of workers that happened in East Germany in June 1953, right after Stalin's death, could be seen as the start of the political upheavals in Eastern Europe in the 1950s, represented here by Poland and Hungary.

24 The Inhwan Choi file is a part of the confidential diplomatic documents of the MFAH. It is now declassified and in possession of the NAH. It consists of 39 microfilms in total. This study replaces the document number with the microfilm number so that general researcher can access them easily. Among the diplomatic confidential documents of the MFAH that are in possession of the NAH, the data from 1949 to 1989 are kept on microfilm. Apart from a few exceptional cases, they are provided to general researchers on microfilm rather than in their original form, so this study provides the roll number and serial number of the microfilm. Bogook Kim has organized the entire list of the data relevant to this period and has published it in the form of a catalogue. For further explanation on the data of North and South Koreas at the NAH, see Balázs Szalontai, Kim Il Sung in the Khrushchev Era (Stanford University Press, 2005), xv-xviii. For the catalogue, see Bogook Kim, Catalogue of Confidential Diplomatic Documents of Ministry of Foreign Affairs of Hungary Related to South and North Koreas (1945-1993) (Bread \& Roses Publishing Co., 2012). 
25 DAROK Class No. 743.73GE/KN 1957-1959. Reg. No. 329. Film No. K0001. Frame No. 0185 .

26 Upon the request of South Korean embassy in Germany, the Hilfsaktion für Flüchtlingsstudenten in der Schweiz, Ungarn Kommission, Zürich, confimed this. The fact that some North Korean overseas students participated in the 1956 Hungarian Revolution appears in the testimony of Herzum Péter, a participant in the revolution. See also Adrienne Molnár, Zsuzsanna Körösi, and Márkus Keller, eds., A forradalom emlékezete: Személyes történelem (Budapest: 56-os Intézet, 2006), 124-241.

27 According to the UNHCR, the Hungarian Revolution created approximately 200,000 refugees. Around 180,000 crossed the Hungary-Austria border, and the rest escaped across the Hungary-Yugoslavia border. See Rupert Colville, Refugees 144.3 (2006): 2.

28 DAROK Class No. 743.73GE/KN 1957-1959. Reg. No. 329. Film No. K0001. Frame No. 0188.

29 Dongcheol Hong, the ambassador of North Korea to Hungary at the time, inquired of the Yugoslavian Embassy there as to the whereabouts of Choi in Yugoslavia, but they claimed not to know. He was later able to confirm that a Yugoslavian institution had helped Choi, however (NAH Roll No. 53706. Frame No. 20080000 0063).

30 The statement that Inhwan Choi wrote in Hungarian says that he arrived in early October 1957, but according to the data from the Hilfsaktion für Flüchtlingsstudenten in der Schweiz, Ungarn Kommission, Zürich, he entered Switzerland on September 7, 1957 (DAROK Class No. 743.73GE/KN 1957-1959. Reg. No. 329. Film No. K0001. Frame No. 0184).

31 Since Switzerland only established diplomatic relations with South Korea on February 11, 1963, there was no Korean embassy in Switzerland. The closest Korean embassy was in Bonn. The consulate became an official embassy in August 1958, and Sohn was appointed ambassador.

32 Hearing that the financial support for Inhwan Choi from the Hilfsaktion für Flüchtlingsstudenten in der Schweiz, Ungarn Kommission, Zürich, was not sufficient, Sohn sent a letter to Yu Chan Yang. In the end, Choi received financial aid (a \$200 initial payment for clothing and \$100 per month for one year as an initial settlement support) from the American-Korean Foundation (DAROK Class No. 743.73GE/KN 1957-1959. Reg. No. 329. Film No. K0001. Frame No. 0192).

33 When Choi applied for a Hungarian entry visa later, he identified himself as South Korean on the application (NAH Roll No. 53706. Frame No. 20080000 0065). In a telegram from the Korean diplomatic office in Bonn, dated February 28, 1958, there is an interview of Choi by Sohn (DAROK Class No. 743.73GE/KN 1957-1959. Reg. No. 329. Film No. K0001. Frame No. 0189-0190). It seems that a South Korean passport was issued to Choi after this interview. In the Korean data, the passport number is not written, but on the application for a Hungarian entry visa, there is a Korean passport number, 23092 (NAH Roll No. 53706. Frame No. 2008 $00000066)$.

34 NAH Roll No. 53706. Frame No. 200800000094

35 Diplomatic relations at ambassador level were established between Switzerland and Hungary in 1963. The Hungarian Consulate in Bern was in charge of the consular work at that time.

36 NAH Roll No. 53706. Frame No. 20080000 0092-0100.

37 NAH Roll No. 53706. Frame No. 20080000 0087-0088.

38 The date of dispatch is unclear, but the letter arrived at the Hungarian Consulate in Bern on December 8, 1959 (NAH Roll No. 53706. Frame No. 20080000 0089).

39 The North Korean ambassador heard that Choi had applied for a Hungarian entry visa from the MFAH and mentioned that Choi had no intention of returning to North Korea in a letter to his family (NAH Roll No. 53706. Frame No. 20080000 0063). 
$40 \quad$ NAH Roll No. 53706. Frame No. 200800000068 and 0070.

41 We can assume that there must have been some prior contact with the Hungarian Consulate to obtain the documents to apply for entry.

$42 \quad$ NAH Roll No. 53706. Frame No. 200800000067.

43 NAH Roll No. 53706. Frame No. 200800000063.

$44 \quad$ NAH Roll No. 53706. Frame No. 200800000073.

$45 \quad$ NAH Roll No. 53706. Frame No. $200800000081-0082$.

$46 \quad$ NAH Roll No. 53706. Frame No. 200800000084.

47 NAH Roll No. 53706. Frame No. 200800000108.

48 NAH Roll No. 53706. Frame No. 200800000110

49 In the case of Hungary, North Korean student Güm-csol Kim, who was studying abroad at Eötvös Loránd University in Budapest at the time, says only a few students were left in Hungary after the war orphans returned to North Korea. Sixty students arrived following a new exchange agreement between the countries in 1983. See Güm-csol Kim, Egy modern Magyar-Koreai szótár koncepciója (1983), S.1, S.n. In the case of the Soviet Union, at least 922 North Korean students enrolled in the Soviet Union's institutions of higher education between 1950 and 1956, after which there were only two more, up to 1966 (See Byelov, quoted in Sin, "Training and Reorganization", 60).

50 In an interview, Chu Jeong said that there was a relatively well-organized anti-Kim Il Sung movement in Moscow around 1956, composed of 10-membered gathering of North Korean students (called 10 Jin Hoe in Korean). See Haeu Koo and Hogeun Song, Genius Musician Chu Jeong Deserted by North Korea (Seoul: Zeitgeist, 2012), 54-64.

$51 \quad$ NAH Roll No. 53706. Frame No. 200800000063.

52 NAH Roll No. 53706. Frame No. 200800000073.

53 Gwon-jin Choi and So-young Kim, "Life Stories of North Korean Students: Lives as Students Studying Abroad and as Refugees in Bulgaria", in The Interrelationship between Bulgaria and Korea after the Second World War (Survey of archives and relevant publications) (2012), 99.

54 Choi and Kim, "Life Stories", 100.

55 According to Hungarian diplomatic documents written in Pyongyang on November 8, 1962, Sangu Lee, a North Korean student at the Moscow Conservatory, requested personal protection from the Soviet Union in 1959. The North Korean embassy asked the Soviet Union to hand him over. The case reached the Central Committee of the Communist Party of the Soviet Union, which decided to comply but, being either unable to wait for the decision or believing that the Soviet Union would not comply, the North Korean embassy kidnapped Lee and tried to smuggle him out of the country by tying him up and putting him in a sack. Upon hearing this news, Khrushchev immediately expelled the North Korean ambassador, Li Szün Phal. According to Third Secretary Fagyejev of the Soviet embassy in Pyongyang, Kim Il Sung mentioned this case only once, saying that the central government knew nothing about it and that the embassy had acted alone (NAH Roll No. 53694. Frame No. 20080000 2320).

56 When students returned from Hungary to North Korea, there was a welcoming convention at Pyongyang Station, at which the students protested at having to return (AFPSU, quoted in Sin, "Training and Reorganization", 68). In addition, after their return, flyers of an inflammatory nature went around the university and dormitory (AFPSU, quoted in Sin, "Training and Reorganization", 69). It might be conjectured that the efforts made to bring unwilling students home were deliberately forceful to minimize any disruption they might cause among the young. In February 1957, the head of the Department of Propaganda and Demagogy of the Central Committee of the Labor Party and the advisor from the Ministry of Foreign Affairs visited educational institutions in Poland, East Germany, the Czech Republic, the Soviet Union, Romania, Bulgaria, and China. The purpose of their visits was to investigate student attitudes 
in the wake of Poland's uprising and the Hungarian Revolution (AFPSU, quoted in Sin, "Training and Reorganization", 69).

57 According to a South Korean diplomatic document (DAROK Class No. $743.73 \mathrm{GE} / \mathrm{KN}$ 1957-1959. Reg. No. 329. Film No. K0001. Frame No. 0188), this includes Inhwan Choi. There is a record of seven students in East Germany visiting the South Korean Embassy in Bonn at the end of 1957 and early 1958 (DAROK Class No. 743.73GE/KN 1957-1959. Reg. No. 329. Film No. K0001. Frame No. 0183, 0193). Two of them escaped to East Germany through West Berlin in 1958 (DAROK Class No.: 743.73GE/KN 1957-1959. Reg. No. 329. Film No. K0001. Frame No. 0193).

58 Kyungmu-dae's response to this report cannot be known precisely, but when looking at the contents of the report that was written by Won Yil Sohn and sent to Kyungmu-dae 20 days after this report was written, it seems Kyungmu-dae was at least not negative about this suggestion and ordered Sohn to make a careful approach (DAROK Class No. 743.73GE/KN 1957-1959. Reg. No. 329. Film No. K0001. Frame No. 0201).

59 "They told me that there are many students, about 400 in East Germany alone, but almost all of them are unhappy at studying under the communists' rules and are wondering whether it is true that they will be able to continue their studies in West Germany if they choose freedom. I have therefore obtained a list of freedom-loving students who, if we could secretly get in touch with them, might come to West Germany. I am enclosing the list, showing 10 individuals who are in Dresden, East Germany. Under the circumstances, I am examining ways to handle this confidentially, and I am considering how we might provide school expenses for so many persons if they come to us. I presume that AKF may be able to take the steps needed to meet the possible increase in assistance" (DAROK Class No. 743.73GE/KN 1957-1959. Reg. No. 329. Film No. K0001. Frame No. 0194).

60 The East Berlin (Spy) Incident, East Berlin (Spy) Case, or East Berlin Affair involved 194 South Korean students and Korean residents living in Germany, France, England, America, and Austria who were suspected in 1967 by the KCIA of communist activity against South Korea as a consequence of visiting the North Korean embassy in East Berlin and North Korea. Diplomatic rows were caused with the host governments because of their compulsory repatriation to South Korea, which included kidnapping.

61 Dong-A Ilbo, July 8, 1967, 1.

62 Korean diplomatic document reports that two North Korean students who escaped could not find the South Korean embassy but then met "our students" by accident in Frankfurt and were led to the embassy (DAROK Class No.: 743.73GE/KN 1957-1959. Reg. No. 329. Film No. K0001. Frame No. 0193). 
